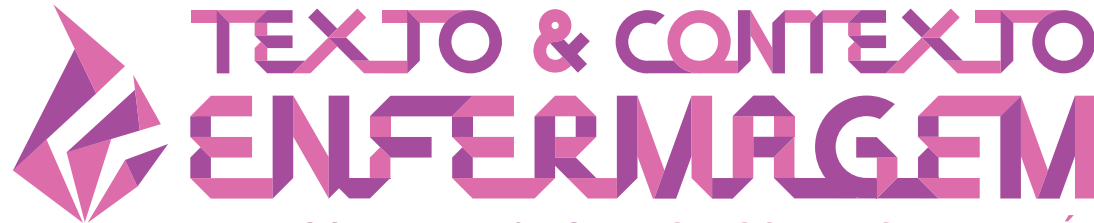

TEXT \& CONTEXT NURSING TEXTO \& CONTEXTO ENFERMERÍA

\section{QUALITY OF LIFE AND BURDEN OF CAREGIVERS OF ELDERLY PEOPLE}

\author{
Andréa Fachini da Costa ${ }^{1}$ (D) \\ Maria Carolina Barbosa Teixeira Lopes ${ }^{1}$ (D) \\ Cássia Regina Vancini Campanharo' ${ }^{1}$ (D) \\ Ruth Ester Assayag Batista ${ }^{1}$ (i) \\ Meiry Fernanda Pinto Okuno' ${ }^{1}$
}

1Universidade Federal de São Paulo, Escola Paulista de Enfermagem. São Paulo, São Paulo, Brasil.

\begin{abstract}
Objective: to assess caregivers' quality of life and correlate it with elderly people's quality of life, as well as assess the burden of caregivers of elderly people hospitalized in an Emergency Service and correlate it with their quality of life.

Method: this is a cross-sectional and analytical study conducted with 250 caregivers of elderly patients admitted to the Emergency Service of Hospital São Paulo, Brazil, from December 2015 to January 2017. To assess caregivers' quality of life, the generic Short-Form-36 questionnaire, item short-form health survey was used; burden was assessed using the Zarit Burden Interview.

Results: the mean age was 48.36 years, with a predominance of females, most of whon were elderly people's children. Caregivers showed mild to moderate burden, and in quality of life assessment, the most compromised domains were general health status, vitality, and social aspects. The Short-Form-36 dimensions that had a significant correlation with Zarit Burden Interview scores were physical aspect, general health status, vitality, social aspects, and emotional aspect.

Conclusion: caregivers' quality of live is associated with elderly people's quality of life. Burden is related to the worsening quality of life of caregivers. It is necessary to identify the work demands and specific needs of caregivers of elderly people in order to develop care strategies involving this population.
\end{abstract}

DESCRIPTORS: Elder. Caregivers. Quality of life. Health promotion. Emergency nursing. 


\section{QUALIDADE DE VIDA E SOBRECARGA DE CUIDADORES DE IDOSOS}

\section{RESUMO}

Objetivo: avaliar a qualidade de vida do cuidador e correlacioná-la com a qualidade de vida do idoso, bem como avaliar a sobrecarga do cuidador de idosos internados no Serviço de Emergência e correlacioná-la com sua qualidade de vida.

Método: estudo transversal e analítico, com 250 cuidadores de idosos internados no Serviço de Emergência do Hospital São Paulo, Brasil, de dezembro de 2015 a janeiro de 2017. Para a avaliação da qualidade de vida dos cuidadores, utilizou-se o questionário genérico Short-Form-36, item short-form health survey; a sobrecarga foi avaliada por meio da escala Zarit Burden Interview.

Resultados: a idade média foi 48,36 anos, com predomínio do sexo feminino, sendo a maioria filhas dos idosos. Os cuidadores apresentaram sobrecarga leve à moderada e na avaliação da qualidade de vida, os domínios mais comprometidos foram: estado geral da saúde, vitalidade e aspectos sociais. As dimensões do Short-Form-36 que tiveram correlação significativa com os escores da Zarit Burden Interview foram aspecto físico, estado geral de saúde, vitalidade, aspectos sociais e aspecto emocional.

Conclusão: a qualidade de vida do cuidador está associada com a qualidade de vida do idoso. A sobrecarga está relacionada com a piora na qualidade de vida do cuidador. Faz-se necessário identificar as demandas de trabalho e necessidades específicas do cuidador de idosos para elaboração de estratégias de cuidado que contemplem essa população.

DESCRITORES: Idosos. Cuidadores. Qualidade de vida. Promoção da saúde. Enfermagem em emergência.

\section{CALIDAD DE VIDA Y SOBRECARGA DE CUIDADORES DE ANCIANOS}

\section{RESUMEN}

Objetivo: evaluar la calidad de vida del cuidador y correlacionarla con la calidad de vida del anciano, así como evaluar la carga del cuidador de los ancianos hospitalizados en el Servicio de Urgencias y correlacionarla con su calidad de vida.

Método: estudio transversal y analítico con 250 cuidadores de ancianos ingresados en el Servicio de Urgencias del Hospital São Paulo, Brasil, de diciembre de 2015 a enero de 2017. Para evaluar la calidad de vida de los cuidadores se utilizó el cuestionario encuesta de salud genérica Short-Form-36, item short-form; La sobrecarga se evaluó mediante la escala Zarit Burden Interview.

Resultados: la edad promedio fue de 48,36 años, con predominio del sexo femenino, siendo la mayoría hijas de ancianos. Los cuidadores mostraron sobrecarga leve a moderada y en la evaluación de la calidad de vida, los dominios más comprometidos fueron: estado general de salud, vitalidad y aspectos sociales. Las dimensiones del Short-Form-36 que tuvieron una correlación significativa con los puntajes de la entrevista Zarit Burden Interview fueron aspecto físico, estado general de salud, vitalidad, aspectos sociales y aspecto emocional.

Conclusión: la calidad de vida del cuidador está asociada con la calidad de vida del anciano. La carga está relacionada con el empeoramiento de la calidad de vida del cuidador. Es necesario identificar las demandas laborales y necesidades específicas del cuidador de ancianos para la elaboración de estrategias de cuidado que contemplen esta población.

DESCRIPTORES: Anciano. Cuidadores. Calidad de vida. Promoción de la salud. Enfermería de urgencia. 


\section{INTRODUCTION}

The world population is aging due to decline in fertility rate and increase in life expectancy. ${ }^{1-3}$ Estimates show that by 2050 the percentage of people aged 60 and older will correspond to approximately $30.0 \%$ of the total population in Brazil. ${ }^{4}$

This demographic transition results in changes in the epidemiological profile of the population's diseases, with an increased prevalence of chronic non-communicable diseases and degenerative diseases, which can result in loss of functional capacity, greater vulnerability and physical dependence of elderly people. ${ }^{5}$

There is an increase in morbidities and functional disability, since with advancing age the probability of problems arising from morphophysiological changes, inherent to aging increases. ${ }^{6}$ Therefore, elderly people are more likely to seek emergency care and are usually admitted to the hospital twice as often as young people. ${ }^{7}$

Possible changes in physical, cognitive and emotional dependence may lead to the need for a caregiver to assist an elderly person in carrying out their activities of daily living. ${ }^{8}$ Throughout the assistance provided to this population, many caregivers experience restrictions in their personal lives when they take on the responsibility of caring and performing tasks continuously. They can face situations of exhaustion, which causes withdrawal from affective and professional relationships, limitation in the social network of socializing, leisure, besides leading to a burden. ${ }^{8}$ This, in turn, can influence the development of psychiatric, physical, emotional, social symptoms and cause the need to use medications. Moreover, the activity of caring for can affect economic life, impair the quality of care offered and compromise caregivers' quality of life (QoL). ${ }^{8}$

The concept of QoL is multidimensional and is related to social, physical, mental, emotional, and spiritual aspects. ${ }^{9}$ When related to health, QoL is an important indicator to assess the impact of a disease on an individual's life. ${ }^{10}$

Considering the aging population and the growing need for the presence of a caregiver to assist the elderly population in carrying out activities of daily living, it was understood that assessing the QoL and burden of caregivers of elderly people will allow implementing specific interventions to caregivers' needs in order to prevent or reduce burden and contribute to improving their QOL.

This study aimed to assess caregivers' QoL and correlate it with elderly people's QoL, assess the burden of caregivers of elderly patients admitted to the Emergency Service (ES) and correlate it with their QoL.

\section{METHOD}

This is a cross-sectional and analytical study conducted with 250 caregivers of elderly patients admitted to the ES of Hospital São Paulo (HSP).

The sample size was calculated using the stratified probabilistic sampling method, proportional to the mean number of patients over 60 years old and assisted in the six months preceding the survey. A degree of reliability greater than or equal to $80 \%$ and an alpha of $5 \%$ were considered, totaling 200 caregivers to achieve the proposed objectives.

Caregivers who perform the function in a period equal to or greater than ninety days and agree to participate in the study were included. Daily, caregivers of elderly hospitalized in ES, who met the inclusion criteria, received instructions on the research and its objectives and were invited to be part of the study.

After explaining the purpose of the research and accepting to participate, everyone signed an Informed Consent Term (ICF). They had their identities preserved and the right of withdrawal guaranteed. 
Data collection was performed by the main researcher for a period of four hours per week from December 2015 to January 2017. The instruments were read in a single moment, with a mean duration of 25 minutes, individually and in a private environment. When participants did not understand a question, the question was repeated slowly until they understood it, without providing clarifications or explanations.

Caregivers' sociodemographic data were obtained through a structured questionnaire with the variables age, sex, and degree of relatedness.

The information of elderly people was collected through interviews with them, from medical records, and their caregivers. The variables collected were related to social, economic, demographic, religious and health beliefs.

To assess elderly people's and caregivers' QoL, the generic Short-Form-36 (SF-36) questionnaire was used, validated and translated in Brazil, ${ }^{11}$ composed of eight dimensions (functional capacity, physical aspect, pain, general health status, vitality, social aspect, emotional aspect, and mental health), with the score for each dimension varying from 0 (worst state) to 100 (best state).

Caregiver burden was assessed using the Zarit Burden Interview (ZBI). This scale has been validated and translated in Brazil, with 22 items, each of which is scored on a Likert scale from 0 to 4 , namely: never $=0$, rarely $=1$, sometimes $=2$, often $=3$ and always $=4$. The total score is calculated by adding all items and can vary from 0 to 88 points. Thus, the higher the score, the greater the caregiver burden. ${ }^{12}$ The score ranging from 61 to 88 points corresponds to severe burden; 41 to 60 , moderate to severe burden; 21 to 40 , mild to moderate burden; less than 21 points, no burden or minimal burden. ${ }^{8}$

For a descriptive analysis of categorical variables, frequency and percentage were used; for continuous variables, mean, standard deviation, median, minimum, and maximum. To correlate sociodemographic, economic, belief and comorbid variables with QoL, the Mann-Whitney nonparametric test was used and, when necessary, the Kruskal-Wallis non-parametric test. Spearman's correlation coefficient was used to relate caregiver burden to his QoL.

For all analyzes, a significance level of $5 \%$ ( $p$ value $<0.05)$ was considered.

\section{RESULTS}

The sample consisted of 250 caregivers of elderly people, with a predominance of female individuals $(77.2 \%)$, mean age of $48.36( \pm 13.39)$ years, most of whon were elderly people's children $(62.4 \%)$.

Table 1 shows caregiver burden, showing a predominance of caregivers with mild to moderate burden (mean=34.17 and SD=15.6).

Table 1 - Measures of centrality of the burden of caregivers of elderly patients admitted to the Emergency Service of Hospital São Paulo, assessed by the Zarit Burden Interview, São Paulo, SP, Brazil. 2016 to 2017. $(n=250)$

\begin{tabular}{lc}
\hline Centrality measures & Zarit Burden Interview \\
\hline Mean (Standard Deviation) & $34.17 \pm 15.6$ \\
Median & 33 \\
Minimum maximum & $1-76$ \\
\hline
\end{tabular}


The QoL domains of caregivers of elderly people hospitalized in ES most compromised were general health status (58.2), vitality (58.4), and social aspects (60.3) (Table 2).

Table 2 - Quality of life of caregivers of elderly patients admitted to the Emergency Service of Hospital São Paulo, São Paulo, SP, Brazil. 2016 to 2017. ( $(n=250)$

\begin{tabular}{lc}
\hline Dimensions & Mean \pm Standard Deviation \\
\hline Physical aspect & $84.9 \pm 32.6$ \\
Emotional aspect & $74.0 \pm 42.1$ \\
Functional capacity & $84.6 \pm 24.5$ \\
Social aspects & $60.3 \pm 29.5$ \\
Vitality & $58.4 \pm 21.5$ \\
Pain & $72.6 \pm 25.7$ \\
General health status & $58.2 \pm 14.4$ \\
Mental health & $67.2 \pm 19.5$ \\
\hline
\end{tabular}

Table 3 shows caregiver burden correlated with their QOL, pointing out that there is a negative correlation, i.e., the higher the level of burden attributed to caregivers, the lower their QoL.

Table 3 - Correlation between burden and quality of life for caregivers of elderly patients admitted to the Emergency Service of Hospital São Paulo, São Paulo, SP, Brazil. 2016 to 2017. (n=250)

\begin{tabular}{lc}
\hline SF-36 Domains & Zarit R $(\mathbf{p}$ value *) \\
\hline Functional capacity & $-0.15(0.0163)$ \\
Physical Aspect & $-0.27(<0.0001)$ \\
Pain & $-0.25(0.0001)$ \\
General Health Status & $-0.35(<0.0001)$ \\
Vitality & $-0.48(<0.0001)$ \\
Social aspects & $-0.53(<0.0001)$ \\
Emotional Aspect & $-0.36(<0.0001)$ \\
Mental health & $-0.49(<0.0001)$ \\
\hline
\end{tabular}

* Spearman's correlation coefficient

When characterizing elderly people who received care, it was observed that the mean age was 71.9 years, male $(56.8 \%)$, with white skin color $(67.2 \%)$, married $(54.0 \%)$, Catholics $(76.0 \%)$, iwith ncomplete elementary school $(33.2 \%)$, retirees or pensioners $(68.8 \%)$, with family income of one to four minimum wages (58.8\%), home providers $(53.6 \%)$, and comorbidities $(81.2 \%)$. The prevalent personal history in the elderly population were cardiovascular diseases 137 (54.8\%), hypertension 104 (41.6\%), and diabetes mellitus 88 (35.2\%).

Concerning elderly people's QoL, the SF-36 dimensions most compromised were physical aspect, emotional aspect, and functional capacity (Table 4). 
Table 4 - Correlation between quality of life of caregivers and quality of life of elderly patients admitted to the Emergency Service of Hospital São Paulo, São Paulo, SP, Brazil. 2016 to 2017. (n=250)

\begin{tabular}{|c|c|c|c|c|c|c|c|c|c|}
\hline \multirow[b]{2}{*}{ SF-36* } & \multicolumn{9}{|c|}{ SF-36 * Caregiver } \\
\hline & atient & FC $\ddagger$ & PA $^{\S}$ & Pain & GHS $\|$ & Vitality & $\mathbf{S A}^{\pi}$ & $\mathrm{EA}^{* *}$ & $\mathbf{M H}^{\dagger \dagger}$ \\
\hline \multirow{2}{*}{$\mathrm{FC}^{\ddagger}$} & $\mathrm{R}$ & 0.03 & 0.12 & 0.10 & 0.02 & 0.17 & 0.22 & 0.13 & 0.17 \\
\hline & $p$ value & 0.6294 & 0.0685 & 0.1284 & 0.7023 & 0.0064 & 0.0005 & 0.0419 & 0.0080 \\
\hline \multirow{2}{*}{$\mathrm{PA}^{\S}$} & $\mathrm{R}$ & 0.10 & 0.07 & 0.09 & 0.03 & 0.08 & 0.12 & 0.06 & 0.15 \\
\hline & $p$ value & 0.1191 & 0.2540 & 0.1394 & 0.6015 & 0.1974 & 0.0590 & 0.3161 & 0.0181 \\
\hline \multirow{2}{*}{ Pain } & $\mathrm{R}$ & 0.10 & 0.19 & 0.15 & 0.13 & 0.22 & 0.21 & 0.19 & 0.21 \\
\hline & $p$ value & 0.1138 & 0.0030 & 0.0143 & 0.0444 & 0.0005 & 0.0009 & 0.0031 & 0.0008 \\
\hline \multirow{2}{*}{ GHS" } & $\mathrm{R}$ & -0.05 & -0.02 & -0.11 & 0.05 & 0.14 & 0.21 & 0.07 & 0.20 \\
\hline & $p$ value & 0.4199 & 0.7304 & 0.0964 & 0.4116 & 0.0274 & 0.0010 & 0.2497 & 0.0013 \\
\hline \multirow{2}{*}{ Vitality } & $\mathrm{R}$ & 0.05 & -0.04 & 0.02 & 0.08 & 0.20 & 0.21 & 0.06 & 0.24 \\
\hline & $p$ value & 0.4777 & 0.4821 & 0.7166 & 0.2016 & 0.0016 & 0.0009 & 0.3416 & 0.0001 \\
\hline \multirow{2}{*}{$S A^{\pi}$} & $\mathrm{R}$ & 0.02 & 0.11 & 0.03 & 0.06 & 0.22 & 0.28 & 0.17 & 0.25 \\
\hline & $p$ value & 0.7729 & 0.0743 & 0.6394 & 0.3625 & 0.0004 & $<0.0001$ & 0.0083 & 0.0001 \\
\hline \multirow{2}{*}{$E A^{* *}$} & $\mathrm{R}$ & 0.04 & 0.09 & 0.06 & -0.08 & 0.08 & 0.16 & 0.11 & 0.07 \\
\hline & $p$ value & 0.5595 & 0.1376 & 0.3096 & 0.2117 & 0.2333 & 0.0092 & 0.0840 & 0.2632 \\
\hline \multirow{2}{*}{$\mathrm{MH}^{+\dagger}$} & $\mathrm{R}$ & 0.00 & 0.04 & 0.03 & 0.14 & 0.28 & 0.28 & 0.14 & 0.30 \\
\hline & $p$ value & 0.9862 & 0.4916 & 0.6341 & 0.0306 & $<0.0001$ & $<0.0001$ & 0.0325 & $<0.0001$ \\
\hline
\end{tabular}

"SF-36 - Quality of Life Assessment; ${ }^{\dagger} F I M$ - Functional Independence Measure; ${ }^{\ddagger} \mathrm{FC}$ - Functional Capacity; \$PA - Physical Aspect; "GHS - General Health Status; ${ }^{\text {ISA }}$ - Social Aspects; ${ }^{* *}$ EA - Emotional Aspect; ${ }^{+} \mathrm{MH}$ Mental Health.

When the SF-36 domains of elderly people hospitalized in ES were related to their caregivers, it was found that the higher the score in elderly people's functional capacity, the higher the scores in the domains of vitality, social aspects, emotional aspect, and mental health of caregivers.

Concerning elderly people's physical aspect dimension, when correlated with caregivers' mental health dimension, it was identified that the higher the score in elderly people's physical aspect dimension, the higher the score in caregivers' mental health dimension.

A positive correlation was also found between elderly people's pain domain and caregivers' physical aspect, pain, general health status, vitality, social, emotional, and mental health domains. The higher the score in elderly people's pain domain, the higher the scores in caregivers' physical aspect, pain, general health status, vitality, mental health and social, and emotional aspects domains.

Other positive correlations were identified between the score of elderly people's general health status dimension and caregivers' vitality, social aspects, and mental health domains and between elderly people's vitality domain and caregivers' vitality, social aspects and mental health domains. The higher the score in elderly people's vitality domain, the higher the scores in caregivers' vitality, social aspects, and mental health domains.

With regards to elderly people's social aspects, the higher the score attributed to them, the higher the scores in caregivers' vitality, mental health, social aspects, and emotional aspects.

Another positive correlation found was between elderly people's emotional aspects and caregivers' social aspects.

There was also a positive correlation between elderly people's mental health dimension and caregivers' general health status, vitality, mental health, social aspects, and emotional aspects domains. 


\section{DISCUSSION}

In this research, caregivers' sociodemographic characteristics were similar to the findings in the scientific literature,$^{10-13}$ with a predominance of females, with a mean age of $48.36( \pm 13.39)$ years, most of whon were elderly people's children (62.4\%). The literature shows that informal care provided by family, friends and neighbors is the most important source of social support for elderly people. ${ }^{9-10}$

Concerning the degree of relatedness in this sample, it was noted that most were composed of elderly people's children. This data is in agreement with a study carried out in Criciúma, Santa Catarina State, which assessed the burden, quality of life and stress in caregivers of three Family Health Strategies, ${ }^{14}$ which may be related to social norms and values. Historically, the female figure was responsible for caring for either the home or children, or even for sick family members. Despite all the social changes and the family composition of the new roles taken over by women, they are still expected to take over the functions of care in general. ${ }^{8}$

In this research, the predominance of caregivers with mild to moderate burden was evidenced. A similar result was obtained in a study with family caregivers of assisted elderly people in two Family Health units, located in the urban area of the municipality of Picos, Piauí State. The mean caregiver burden was 26.5 points, 15 as well as in a study ${ }^{15}$ carried out by researchers from the Graduate Program in Gerontology at Universidade Estadual de Campinas (Unicamp), in four São Paulo municipalities that assessed work burden in caregivers of elderly people who exercised informal care for an elderly relative, identifying moderate burden, with a mean of 26.1 points. ${ }^{16}$

Caregivers without formal preparation, knowledge or adequate support to provide assistance to elderly patients, in addition to burden, may also suffer negative consequences on their QoL. ${ }^{14-15}$

As for QoL assessment, the caregivers of this present study had scores more compromised in general health status, vitality, and social aspects dimenions. These findings corroborate those reported in a study conducted in Rio Grande do Norte State, which measured caregivers' QoL of institutionalized elderly people. ${ }^{17}$ The lowest scores in general health status, vitality, and social aspects domains seem to be related to the task of caring, since items such as low energy and vigor, exhaustion, fatigue, unwillingness and tiredness are investigated in the assessments of these dimensions; ${ }^{10}$ therefore, this result suggests that it is a consequence of overwork. ${ }^{17}$

However, all other scores of the SF-36 dimensions in the current study had higher scores when compared to another survey conducted with caregivers of Home Care Service users in the city of Goiânia, Brazil. ${ }^{18}$ This result may be related to the fact that the caregivers of this study have provided assistance to elderly people with their impaired functional capacity. Another study carried out with caregivers of elderly people registered in two Family Health Units in Piauí also had a lower score in the general health status dimension. ${ }^{15}$

This research showed that the SF-36 dimensions, which had a significant correlation with ZBI scores, were physical aspect, general health status, vitality, social aspects, and emotional aspect, which indicate low energy level, fatigue, impaired social integration and greater emotional lack of control by caregivers, which emphasizes the relationship between work burden and impaired QoL. ${ }^{10}$

It was observed in this study that the better elderly people's QoL, the better caregivers' QoL.

The association between caregivers' QoL and elderly people's QoL, starting with SF-36, showed a significant correlation $(p<0.0001)$ between elderly people' social aspects with caregivers' social aspects and between elderly people' mental health with caregivers' vitality, social aspect, and mental health.

A study carried out with family caregivers of frail elderly people in China corroborates these findings. In that study, the performance of elderly people in activities of daily living was assessed using the Barthel Scale, measuring satisfaction with caregivers' lives by the Satisfaction with Life 
Scale, concluding that caregivers with greater psychological well-being cared for elderly people with less cognitive impairment and less dependence on activities of daily living. ${ }^{19}$

A research conducted with informal Portuguese caregivers, which assessed the ability of elderly people to perform basic and instrumental activities of daily living using Barthel and Lawton scales, elderly people's cognitive function through the Mini Mental State Examination, and caregiver burden by the Caregiver Burden Scale, identified that individuals who provided assistance to elderly people with mental impairment reported a lower level of satisfaction compared to individuals who provided assistance to elderly people with physical impairment. ${ }^{20}$

These findings show that the type of impairment and elderly people's health conditions can influence caregivers' QoL. It is considered that the greatest physical and/or cognitive impairment of elderly people implies an increase in the demand for care provided, which can generate physical and psychological burden for caregivers. ${ }^{21}$

Considering the aging population and the greater need for the presence of caregivers of elderly people, it is necessary that health professionals, especially nurses, identify the work demands, difficulties and health conditions of the caregivers, enabling them to act efficiently and to exercise their function with less risk to their physical and mental health.

\section{CONCLUSION}

The caregivers of elderly people hospitalized in ES had a mean age of 48.36 years, with a predominance of females, most of whon were elderly people's children. A predominance of family caregivers with mild to moderate burden was identified.

The most compromised domains in QoL were general health status, vitality, and social aspects. The SF-36 dimensions, which had a significant correlation with ZBI scores, were physical aspect, general health status, vitality, social aspects, and emotional aspect.

The results indicate that the more compromised elderly people's QoL, the greater the burden of care provided and the worse caregivers' QoL.

As a limitation of this study, we cite a cross-sectional design that does not allow establishing causality and the fact that it was carried out in a single center that provides assistance to patients in the public health system, which may not represent other realities.

Therefore, it was concluded that assessing the QoL of caregivers of elderly hospitalized in ES and work burden attributed to them will enable developing effective actions for health promotion, with a view to preventing and/or reducing burden and QoL improvement, since physical and emotional burden can cause them to become ill.

Therefore, given the relevance of the subject, it is suggested that further research be developed given the scarcity of the proposed theme.

\section{REFERENCES}

1. World Health Organization. World report on ageing and health. Geneva(CH): WHO. [Internet]. 2015 [cited 2018 Sept 05]. Available from: https://www.who.int/ageing/events/world-report-2015launch/en/

2. Santos Júnior EB, Oliveira LPAB, Silva RAR. Chronic non-communicable diseases and the functional capacity of elderly people. J Res Fundam Care Online [Internet]. 2014. [cited 2018 Sept 06];6(2):516-24. Available from: https://doi.org/10.9789/2175-5361.2014v6n2p516

3. Campos ACV, Ferreira, Vargas AMD, Gonçalves LHT. Healthy aging profile in octogenarians in Brazil. Rev Latino-Am Enfermagem [Internet]. 2016 [cited 2019 Oct 20];24:e2724. Available from: https://doi.org/10.1590/1518-8345.0694.2724 
4. Cruz DT, Vieira MT, Bastos RR, Leite ICG. Factors associated with frailty in a community-dwelling population of older adults. Rev Saúde Pública [Internet]. 2017[cited 2018 Sept 03];51:107. Available from: https://doi.org/10.11606/S1518-8787.2017051007098

5. Okuno MFP, Rosa AS, Lopes MCBT, Campanharo CRV, Batista REA, Belasco AGS. Quality of life of hospitalized octogenarians. Texto Contexto Enferm [Internet]. 2019 [cited 2019 Oct 20]; 28:e20180207. Available from: https://doi.org/10.1590/1980-265x-tce-2018-0207

6. Berlizi EM, Farias AM, Oliveira KR, Pillatt AP, Fortes CK. Analysis of the functional capacity of elderly residents of communities with a rapid population aging rate. Rev Bras Geriatr Gerontol [Internet]. 2016 [cited 2018 Sept 23];19(4):643-52. Available from: https://doi.org/10.1590/180998232016019.150156

7. Rosenberg M, Rosenberg L. The geriatric emergency department. Emerg Med Clin North AM. 2016 [cited 2018 Sept 23];34(3):629-48 Available from: https://doi.org/10.1016/j.emc.2016.04.011

8. Jesus ITM, Orlandi AAS, Zazzetta MS. Burden, profile and care: caregivers of socially vulnerable elderly persons. Rev Bras Geriatr Geronto [Internet]. 2018. [cited 2019 Oct 23];21(2):194-204. Available from: https://doi.org/10.1590/1981-22562018021.170155

9. Bornet MA, Rubli Truchard E, Rochat E, Pasquier J, Monod S. Factors associated with quality of life in elderly hospitalised patients undergoing post-acute rehabilitation: a cross-sectional analytical study in Switzerland. BMJ Open [Internet]. 2017 [cited 2018 May 24];7(10):e018600. Available from: https://www.ncbi.nlm.nih.gov/pubmed/29061633

10. Oliveira DC, Carvalho GSF, Stella F, Higa CMH, D'elboux MJ. Quality of life and work overload among elderly Outpatient caregivers. Texto Contexto Enferm [Internet]. 2011 [cited 2018 Oct 10];20(2):234-40. Available from: https://doi.org/10.1590/S0104-07072011000200003

11. Ciconelli RM, Ferraz MB, Santos W, Meinão I, Quaresma MR. Brazilian-Portuguese version of the SF-36. A reliable and valid quality of life outcome measure. Rev Bras Reumatol [Internet]. 1999 [cited 2018 Oct 08];39(3):143-50. Available from: http://www.ufjf.br/renato_nunes/files/2014/03/ valida\%c3\%a7\%c3\%a3o-do-question\%c3\%a1rio-de-qualidade-de-vida-sf-36.pdf

12. Scazufca M. Brazilian version of the Burden Interview scale for the assessment of burden of care in carers of people with mental illnesses. Rev Bras Psiquiatr [Internet]. 2002. [cited 2018 Oct 13];24(1):12-7. Available from: https://doi.org/10.1590/S1516-44462002000100006

13. Nunes DP, Brito TRP, Duarte YAOliveira, Lebrão ML. Caregivers of elderly and excessive tension associated to care: evidence of the Sabe Study. Rev Bras Epidemiol [Internet]. 2018 [cited 2019 Oct 28];21(Suppl 2):e180020. Available from: https://doi.org/10.1590/1980-549720180020.supl.2

14. Souza LR, Hanus JS, Libera LBD, Silva VM, Mangilli EM, Simões PW, et al. Overload in care, stress and impact on the quality of life of surveyed caregivers assisted in primary care. Cad Saúde Colet [Internet]. 2015 [cited 2019 Oct 23];2:140-9. Available from: https://doi.org/10.1590/1414462X201500020063

15. Rodrigues JEG, Machado ALG, Vieira NFC, Fernandes AFC, Rebouças CBA. Quality of life and work overload in family caregivers of elderly. Cienc Enferm [Internet]. 2014 [cited 2018 Oct 23]; 20(3):119-29. Available from: https://doi.org/10.4067/S0717-95532014000300011

16. Bianchi M, Flesch LD, Alves EV, Batistoni SS, Neri AL. Zarit Burden Interview Psychometric Indicators Applied in Older People Caregivers of Other Elderly Rev Latino-Am Enfermagem [Internet]. 2016 [cited 2018 Oct 23];24:e2835. Available from: https://doi.org/10.1590/15188345.1379.2835

17. Barbosa LM, Noronha K, Spyrides MHC, Araújo CAD. Qualidade de vida relacionada à saúde dos cuidadores formais de idosos institucionalizados em Natal, Rio Grande do Norte. Rev Bras Estud Popul [Internet]. 2017 [cited 2018 Oct 25];34(2):391-414. Available from: https://doi. org/10.20947/s0102-3098a0004 
18. Guerra HS, Almeida NAM, Souza MR, Minamisava R, Tobias GC. Quality of life of caregivers at a home care service. Rev Enferm UFPE on line [Internet]. 2017 [cited 2019 Oct 25];1(Supl. 1): 254-63. Available from: https://doi.org/10.5205/reuol.7995-69931-4-SM.1101sup201702

19. Lethin C, Renom-Guiteras A, Zwakhalen S, Soto-Martin M, Saks K, Zabalegui A, et al. Psychological well-being over time among informal caregivers caring for persons with dementia living at home. Aging Ment Health. [Internet] 2017 [cited 2018 Oct 25];21(11):1138-46. Available from: https:// doi.org/10.1080/13607863.2016.1211621

20. Sequeira C. Difficulties, coping strategies, satisfaction and burden in informal Portuguese caregivers. J Clin Nurs [Internet] 2013 [cited 2018 Oct 28];22(3-4):491-500. Available from: https://doi.org/10.1111/jocn.12108

21. Flesch Ld, Batistoni SST, Neri AL, Cachioni M. Psychological aspects of the quality of life of caregivers of the elderly: an integrative review. Geriatr Gerontol Aging [Internet] 2017 [cited 2018 Oct 28];11(3):138-49. Available from: https://doi.org/10.5327/Z2447-211520171700041 


\section{NOTES}

\section{CONTRIBUTION OF AUTHORITY}

Study design: Costa AF, Lopes MCBT, Campanharo CRV, Batista REA, Okuno MFP.

Data collection: Costa AF, Lopes MCBT, Campanharo CRV, Batista REA, Okuno MFP.

Data analysis and interpretation: Lopes MCBT, Campanharo CRV, Batista REA, Okuno MFP.

Discussion of results: Costa AF, Lopes MCBT, Campanharo CRV, Batista REA, Okuno MFP.

Writing and/or critical review of content: Lopes MCBT, Campanharo CRV, Batista REA, Okuno MFP.

Final review and approval of the final version: Lopes MCBT, Campanharo CRV, Batista REA, Okuno MFP.

\section{APPROVAL OF ETHICS COMMITTEE IN RESEARCH}

This study was approved by the Research Ethics Committee of Universidade Federal de São Paulo, under Opinion 1,232,171 and CAAE (Certificado de Apresentação para Apreciação Ética - Certificate of Presentation for Ethical Consideration) 47056515.6.0000.5505.

\section{CONFLICT OF INTERESTS}

There was no conflict of interest.

\section{HISTORY}

Receveid: February 26, 2019.

Approved: February 05, 2020.

\section{CORRESPONDING AUTHOR}

Andréa Fachini da Costa

defacosta@hotmail.com 